\title{
Research on the Spatial Distribution Pattern and Influencing Factors of China's Antipoverty (Pro-Poor Tourism) on GIS
}

\author{
Qing Yang $\mathbb{D},{ }^{1}$ Fengtai Zhang $\mathbb{D},{ }^{1}$ Youzhi An, ${ }^{1}$ Changcheng Sun, ${ }^{1}$ Jianfeng Wu, ${ }^{2}$ Yue Zhang, \\ and Zhen Wei ${ }^{1}$ \\ ${ }^{1}$ School of Management, Chongqing University of Technology, Chongqing 400054, China \\ ${ }^{2}$ School of Geography and Resources, Guizhou Normal University, Guiyang 550018, China \\ Correspondence should be addressed to Fengtai Zhang; zhfthero45@cqut.edu.cn
}

Received 8 December 2020; Revised 22 January 2021; Accepted 11 March 2021; Published 26 March 2021

Academic Editor: Jose Luis Calvo-Rolle

Copyright (c) 2021 Qing Yang et al. This is an open access article distributed under the Creative Commons Attribution License, which permits unrestricted use, distribution, and reproduction in any medium, provided the original work is properly cited.

\begin{abstract}
Eliminating poverty is the common mission of all mankind, and it is also an important task faced by many countries. Pro-poor tourism villages are an active attempt by China to use rural tourism to escape poverty. This paper aims to provide theoretical support for consolidating the results of poverty alleviation and achieving comprehensive poverty alleviation and to provide a scientific basis for policy formulation by using GIS spatial analysis to study the spatial distribution characteristics and influencing factors of 22,651 pro-poor tourism villages in China. The findings revealed that the spatial distribution of pro-poor tourism villages is roughly divided by the $\mathrm{Hu}$ line. Pro-poor tourism villages show an uneven agglomeration pattern and present a spatial pattern of dense southeast and sparse northwest with six high-density core areas, among which some cities in the southwest are $\mathrm{H}-\mathrm{H}$ agglomeration areas. Specifically, topography, annual rainfall, endowment of tourism resources, location transportation, and policy orientation are important factors affecting the spatial distribution of pro-poor tourism villages.
\end{abstract}

\section{Introduction}

Poverty is a phenomenon that exists all over the world [1]. Pro-poor tourism is a way of poverty alleviation in povertystricken areas by using local tourism resources to promote economic, cultural, and social development and increase local residents' income [2]. Compared with other poverty alleviation models, pro-poor tourism not only brings economic effects but also brings cultural, environmental, and social effects and improves the cultural literacy of people in poverty alleviation areas, and it can realize the integrated development of the primary, secondary, and tertiary industries [3]. Pro-poor tourism emphasizes that the tourism benefits of the poor must be far greater than the costs they pay [4]. In the framework of the pro-poor tourism, the poor population is the core, and it directly focuses on the tourist destinations and their tourism practices in poor areas, especially the situation related to the poor population [5]. Propoor tourism has become an important method for many countries and regions to eliminate poverty and improve people's livelihood, and its poverty alleviation effect has attracted global attention [6]. Many countries have combined tourism development with poverty alleviation policies and achieved good results [7]. For example, pro-poor tourism has made great achievements in China. From 2012 to 2019, China's poor population dropped from 98.99 million to 5.51 million. Pro-poor tourism is an important decision for the development of inland China and ethnic minority areas, and an important means for poor agricultural areas to develop a diversified market economy [8]. Tourism poverty alleviation villages refer to poor villages in rural areas and are the smallest spatial representation and basic organizational unit of poverty in rural areas. China takes the complete poverty alleviation of the rural population as the bottom line and goal of building a well-off society by 2020 . As of the end of February 2020, there are still 52 impoverished counties and 2,707 impoverished villages in China, and the poverty alleviation work has entered the most difficult stage (The State Council Leading Group Office of Poverty Alleviation and Development, 2020). Antipoverty is 
currently one of the most urgent and most significant research topics in China.

The concept of pro-poor tourism (PPT) was first proposed by The Department for International Development at the end of the 1990s, which means tourism is beneficial to the poor [9]. Mowforth et al. [10] deeply discussed how poor areas can achieve the goal of poverty alleviation through the development of eco-tourism, making pro-poor tourism research become the hotspot. The research content mainly focused on the concept of pro-poor tourism $[9,11]$, the theory of pro-poor tourism $[12,13]$, the relationship between tourism and poverty alleviation $[14,15]$, and the exploration of pro-poor tourism models $[16,17]$. At the same time, through long-term exploration, poverty-stricken areas have gradually realized that, in order to ensure the sustainable development of pro-poor tourism, it is necessary to pay more attention to government guidance and effective participation of community and promote the balanced and coordinated development of various stakeholders on the basis of spontaneous market adjustments [18]. Scheyvens [19] puts forward the viewpoint that poor areas and governments should pay attention to community participation in the process of promoting pro-poor tourism. Since then, some scholars have found that tourism community organizations can promote tourism poverty alleviation work [20]. Scheyvens et al. [21] further discussed the contribution of different tourism companies to pro-poor tourism. With the development of pro-poor tourism work, scholars have gradually shifted from the macrolevel to the microlevel to evaluate the benefits of pro-poor tourism [22-24] study propoor tourism cases $[21,25]$ and community tourism $[26,27]$. Qin et al. [28] pointed out that the noncoordinated development relationship between tourism poverty alleviation and ecological environments is significant. The research methods of pro-poor tourism are mostly based on qualitative research, and the research cases are mainly concentrated in African countries and other underdeveloped countries and regions in Southeast Asia [29]. In general, there had been a large number of excellent research results, and the research on pro-poor tourism is mainly qualitative research from the perspectives of management, economics, and tourism [30]. However, the research on pro-poor tourism rarely involves quantitative research and even less systematic research from the perspective of geography, just like the research on the spatial distribution characteristics and influencing factors of pro-poor tourism villages. Therefore, this paper uses mathematical statistical analysis and GIS spatial statistical analysis methods to study the spatial distribution pattern of 22,651 pro-poor tourism villages in China and further explores the influencing factors of its spatial distribution.

The key contributions of this paper are as follows. (1) We expect to broaden the depth and breadth of pro-poor tourism from the perspective of geographic research and deepen the understanding of the factors affecting the spatial distribution of pro-poor tourism areas. It can be regarded as a progress in the study of spatial antipoverty theory in China. (2) It can provide theoretical support for consolidating the poverty alleviation achievements of pro-poor tourism villages, accelerate the development of rural leisure tourism in pro-poor tourism villages, and provide a scientific basis for government departments to improve policy support for the integration of agriculture and tourism. (3) China is a typical developing country. Using rural tourism to get rid of poverty can provide reference for other countries in the world to get rid of poverty.

\section{Materials and Methodology}

2.1. Data Collection and Preprocessing. We obtain list of propoor tourism villages from "Action Plan of Rural Tourism Poverty Alleviation Project" declared by Ministry of Culture and Tourism of the People's Republic of China. There are 22,651 villages in China selected as national pro-poor tourism villages, and the research scope does not include Hong Kong, Macao, and Taiwan provinces. We use Baidu Map to obtain the geographic coordinates of each pro-poor tourism village and use ArcGIS 10.3 software to visually mark the pro-poor tourism villages on the map of China with point elements to draw the spatial distribution map of China's pro-poor tourism villages (Figure 1). The base map of spatial analysis is taken from the basic geographic information database of National Catalogue Service for Geographic Information. The scenic spots data is taken from the "Statistics of China's A-level scenic spots in 2018." The annual rainfall data comes from China Meteorological Administration. The data of contiguous destitute areas come from the "China Agricultural Poverty Alleviation and Development Program (2011-2020).”

2.2. Nearest Neighbor Index. The pro-poor tourism villages were abstracted as point elements. The proximity of propoor tourism villages in geographic space can be expressed by the nearest neighbor distance, which can well reflect the spatial distribution type of pro-poor tourism villages. Generally, the spatial distribution of pro-poor tourism villages can be summarized into three types: aggregate distribution, uniform distribution, and random distribution [31].

$$
\begin{gathered}
R=\frac{\overline{r_{1}}}{r_{E}}=2 \sqrt{D} \times \overline{r_{1}}, \\
\overline{r_{E}}=\frac{1}{\sqrt[2]{n / A}}=\frac{1}{2 \sqrt{D}} .
\end{gathered}
$$

In the above formula, $R$ represents the nearest neighbor index, $\bar{r}_{1}$ represents the average distance between neighboring pro-poor tourism villages, $\bar{r}_{E}$ represents the theoretical average distance of pro-poor tourism villages, $D$ represents the point density, $n$ represents the number of pro-poor tourism villages, and $\mathrm{A}$ indicates the area of the study area. When $R=1$ and $\bar{r}_{1}=\bar{r}_{E}$, it means that the pro-poor tourism villages are randomly distributed; when $R>1$ and $\bar{r}_{1}<\bar{r}_{E}$, it means that the pro-poor tourism villages are uniform distributed; when $R<1$ and $\bar{r}_{1}<\bar{r}_{E}$, indicating that pro-poor tourism villages are agglomerated distribution, and the smaller the $R$, the higher the concentration of pro-poor tourism villages. 


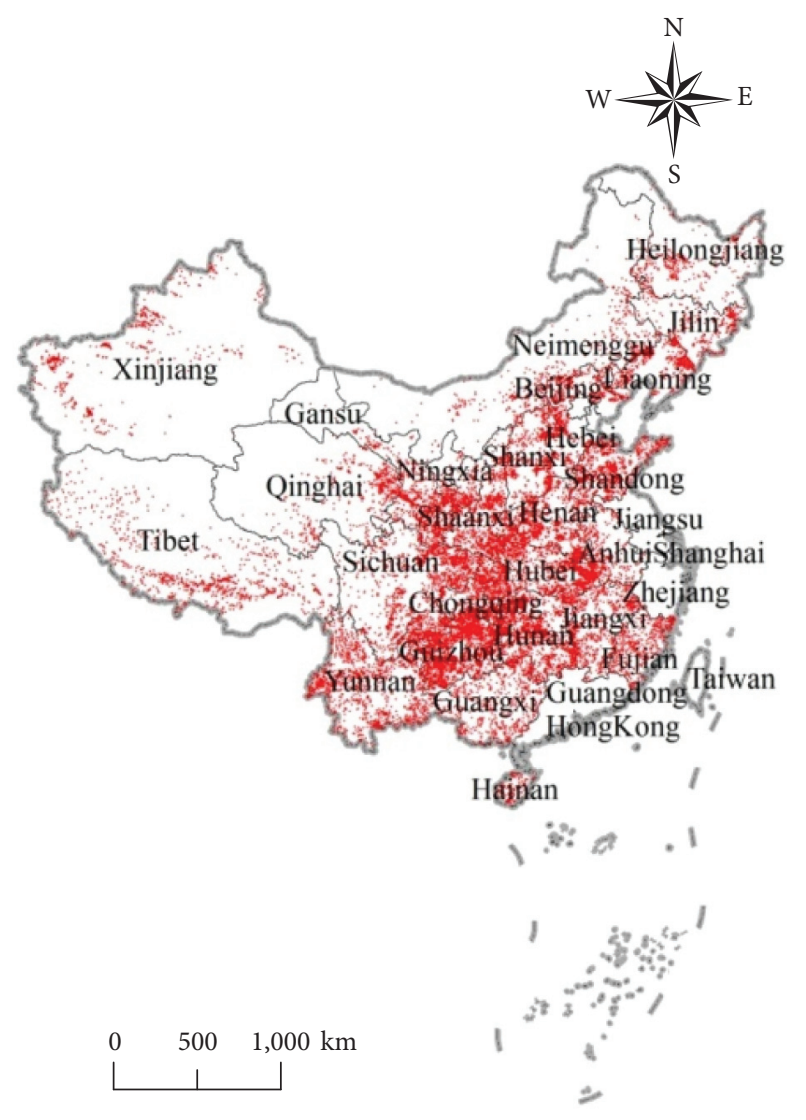

Pro-poor tourism villages

_-... National boundaries

FIGURE 1: Distribution map of pro-poor tourism villages in China.

2.3. Kernel Density Estimation. Kernel density estimation $(\mathrm{KDE})$ is a common nonparametric estimation in spatial analysis. It is a kind of spatial smoothing method to calculate the degree of agglomeration of samples in the characterization area according to the input sample data [32]. The result can be used to smoothly identify and express the agglomeration and dispersion of samples in the study area [33]. This study adopts the kernel density function (KDF) proposed by Silverman [34] and uses ArcGIS 10.3 to analyze the spatial distribution of pro-poor tourism villages:

$$
\tilde{\lambda}_{h}(s)=\sum_{i=1}^{n} \frac{3}{\pi h^{4}}\left(1-\frac{\left(s-s_{i}\right)^{2}}{h^{2}}\right)^{2} .
$$

In the above formula, $\tilde{\lambda}_{h}(s)$ represents the value of kernel density estimation, $s$ represents the location of the pro-poor tourism village to be estimated, and $s_{i}$ represents the $i$ th propoor tourism village in the circle, where $s$ is the center and is the radius.

2.4. Spatial Correlation Analysis. The first law of geography states that there is a correlation between everything, and the closer the distance between things, the higher the correlation [35]. The method to test the correlation between the elements is usually spatial autocorrelation analysis. Spatial autocorrelation analysis is a kind of spatial correlation analysis, which is divided into global autocorrelation analysis and local autocorrelation analysis. The global autocorrelation analysis can measure the agglomeration characteristics of elements in the entire region. The article uses Moran's I index to analyze the autocorrelation of propoor tourism villages, and the global Moran's I index is calculated as follows :

$$
I=\frac{n \times \sum_{i=1}^{n} \sum_{j=1}^{n} W_{i j}\left(x_{i}-\bar{x}\right)\left(x_{j}-\bar{x}\right)}{\left(\sum_{i=1}^{n} \sum_{j=1}^{n} W_{i j}\right) \times \sum_{i=1}^{n}\left(x_{i}-\bar{x}\right)^{2}} .
$$

In the above formula, I represents Moran's I index, $I \in[-1,1]$, n represents the number of regions, $x_{i}$ and $x_{j}$ represent the observation values of the pro-poor tourism villages at locations $i$ and $j$, respectively, $\bar{x}$ represents the average number of pro-poor tourism villages, $\left(x_{i}-\bar{x}\right)\left(x_{j}-\bar{x}\right)$ represents the similarity of the observational value of the pro-poor tourism villages in regions $i$ and $j$, and $W_{i j}$ represents the weight matrix of the location of regions $i$ and $j$. There are usually many forms of spatial weights, we used GeoDa software to create a neighborhood weight (k-nearest) based on the number of pro-poor tourism villages in the region, set the number of neighbors to 6 , and perform global autocorrelation analysis.

The global autocorrelation analysis can only judge the overall spatial distribution of pro-poor tourism villages in a region, but local spatial autocorrelation analysis can further measure whether the pro-poor tourism villages gather in local space and the specific location of the gathering. The specific calculation formula of the local Moran index is as follows :

$$
I_{i}=\frac{\left(x_{i}-\bar{x}\right)}{m_{0}} \sum_{j=1}^{n} W_{i j}\left(x_{j}-\bar{x}\right) .
$$

In the above formula, $x_{i}$ represents the number of propoor tourism villages in area $i, x_{j}$ represents the number of pro-poor tourism villages in area $j$, and $\bar{x}$ represents the average of the number of pro-poor tourism villages in all areas. If $I_{i}>0$, it means that the number of pro-poor tourism villages in the adjacent area is similar, showing spatial agglomeration ( $\mathrm{H}-\mathrm{H}$ or L-L).

The visualized Moran scatter diagram has 4 quadrants, which, respectively, represent the 4 types of local spatial relationships in adjacent areas. The first quadrant $(\mathrm{H}-\mathrm{H})$ indicates that the number of pro-poor tourism villages in adjacent areas is similar, both are large, and the spatial internal heterogeneity is small. The second quadrant $(\mathrm{L}-\mathrm{H})$ indicates that there are few pro-poor tourism villages in a certain area, but there are many tourist poverty alleviation villages in the adjacent area, and the spatial internal heterogeneity is large. The third quadrant (L-L) indicates that the number of pro-poor tourism villages in adjacent areas is similar, both are less, and spatial internal heterogeneity is small. The fourth quadrant $(\mathrm{H}-\mathrm{L})$ shows that there are many pro-poor tourism villages in a certain area, but there are few in adjacent areas, and the internal spatial heterogeneity is large. On the one hand, the LISA cluster map can evaluate 
the agglomeration significance of the local space around the observation area, and on the other hand, it can reveal the regions that have a greater impact on the global correlation and the correlation forms between different areas.

\section{Spatial Distribution Characteristics}

3.1. Spatial Distribution Type. We have calculated the nearest neighbor index of pro-poor tourism villages in China and different provinces through ArcGIS 10.3 (Table 1), $R<1$, and the spatial distribution type of pro-poor tourism villages is agglomeration, but the degree of agglomeration is different. The nearest neighbor index of pro-poor tourism villages in Xinjiang is the smallest, and its degree of agglomeration is the highest; the nearest neighbor index of pro-poor tourism villages in Fujian is the largest, and its degree of agglomeration is the lowest. The spatial distribution type of pro-poor tourism villages in various provinces may indicate that tourism poverty alleviation has been well developed in each province, and each province has generally formed a certain scale and relatively concentrated rural tourism antipoverty destination, reflecting the good development of China's tourism antipoverty stage.

\subsection{Degree of Agglomeration and Diffusion of Spatial} Distribution. There are a large number of pro-poor tourism villages in China, and they are widely distributed. We used ArcGIS 10.3 to measure the spatial distribution density of 22,651 pro-poor tourism villages, divide the distribution density of tourism poverty alleviation villages into five levels, and draw a nuclear density map of the spatial distribution of China's pro-poor tourism villages (Figure 2(a)). The figure shows the overall spatial distribution of China's pro-poor tourism villages is dense in the southeast and sparse in the northwest; with significant spatial density characteristics, roughly taking the $\mathrm{Hu}$ Line 1 as the dividing line, most of the tourism poverty alleviation villages are located on the southeast side of the $\mathrm{Hu}$ Line. Obviously, the spatial pattern of China's antipoverty is not consistent with the spatial pattern of economic and population development. If the traditional thesis that economic growth can eliminate poverty is established, we will not be able to observe this spatial distribution of poverty in rural China. It shows that China's antipoverty spatial agglomeration characteristics are not closely related to economic growth. From a regional perspective, the spatial density of pro-poor tourism villages presents a "core" distribution, mainly forming two big core areas at the intersection of Guizhou and Hunan Provinces and Hubei and Anhui Provinces, forming four small core areas in Guizhou Province, Hunan Province, Sichuan Province, and the intersection of Shanxi and Shandong Provinces.

3.3. Correlation of the Spatial Distribution. We used GeoDa to conduct autocorrelation analysis on pro-poor tourism villages, and the $Z$ value is greater than 2.58 and the $P$ value is less than 0.01 , passing the significance test at the $99 \%$ confidence level (Table 2). From the perspective of global autocorrelation, Moran's I index of pro-poor tourism villages on the three spatial scales of province, city, and county are all greater than 0 , indicating that the spatial distribution of pro-poor tourism villages presents a positive spatial autocorrelation and there are $\mathrm{H}-\mathrm{H}$ and L-L spatial agglomeration areas. As the scale of the research space gradually decreases from province to county, the Moran index of tourism poverty alleviation villages first increases and then decreases. It shows that the agglomeration degree and spatial autocorrelation of tourism poverty alleviation villages first increase and then decrease. The spatial autocorrelation of tourism poverty alleviation villages is the strongest at the city scale and the weakest at the provincial scale.

From the perspective of local spatial autocorrelation, at the provincial scale (Figure 2(b)), there are no H-L agglomeration areas, L-L and L-H agglomeration areas are all small, and $\mathrm{H}-\mathrm{H}$ agglomeration areas have the largest area, concentrated in Yunnan, Guizhou, Sichuan, Hunan, and other provinces. At the city scale (Figure 2(c)) and county scale (Figure 2(d)), L-H and H-L agglomeration areas are distributed sporadically, $\mathrm{H}-\mathrm{H}$ agglomeration areas are relatively concentrated, forming two large agglomeration areas in the middle of the Tibet and Yunnan, Guizhou, Sichuan, Chongqing, and Hunan provinces, and L-L agglomeration areas are distributed and more scattered, but larger in size, mainly concentrated in coastal and border areas. In general, the distribution space of $\mathrm{H}-\mathrm{H}$ agglomeration areas has overlapped, that is, the areas where pro-poor tourism villages are concentrated in southwest China, which is more consistent with the results of the kernel density estimation of pro-poor tourism villages. These areas are the growth poles of tourism antipoverty, and the number of tourism poverty alleviation villages is much higher than that of the surrounding areas. On the one hand, it shows that these areas have achieved remarkable results in antipoverty and formed core areas. On the other hand, it also reflects that these areas have a high incidence of poverty and are the main battlefield for antipoverty, requiring more support from policies, funds, and poverty alleviation industries. L-L agglomeration areas also have obvious overlap at the city and county scales. The sparse areas of pro-poor tourism villages are concentrated in the coastal plains and economically developed areas. These areas are economically developed and relatively few propoor tourism villages. The spillover effects of foreign trade, factor flow, remuneration transfer, and technology diffusion in these areas are significant, leading to a low incidence of poverty and naturally forming antipoverty low-value agglomeration areas.

\section{Influencing Factors}

4.1. Topography and Landform. Topography has an important impact on human production and life. Pro-poor tourism villages are based on agricultural production, rural life, and rural tourism and have certain requirements for the natural ecological environment. There are big differences in precipitation and temperature in areas where pro-poor tourism villages are affected by altitude. Therefore, the article analyzed the influence of altitude on the spatial distribution 
TABLE 1: The nearest neighbor index of pro-poor tourism villages.

\begin{tabular}{|c|c|c|c|c|c|c|c|}
\hline Area & $\overline{\mathbf{r}}_{\mathbf{i}}(\mathrm{km})$ & $\overline{\mathbf{r}}_{\mathrm{E}}(\mathrm{km})$ & $\mathbf{R}$ & Area & $\overline{\mathbf{r}}_{\mathbf{i}}(\mathrm{km})$ & $\overline{\mathbf{r}}_{\mathrm{E}}(\mathrm{km})$ & $\mathbf{R}$ \\
\hline Nationwide & 5.86 & 13.79 & 0.43 & Henan & 4.71 & 8.04 & 0.59 \\
\hline Xijiang & 9.29 & 23.75 & 0.39 & Chonging & 5.11 & 8.36 & 0.61 \\
\hline Gansu & 5.48 & 12.41 & 0.44 & Helongjiang & 11.69 & 18.87 & 0.62 \\
\hline Hebei & 4.61 & 9.94 & 0.46 & Ningxia & 7.08 & 11.21 & 0.63 \\
\hline Tibet & 8.23 & 1.76 & 0.47 & Hubei & 4.25 & 6.74 & 0.63 \\
\hline Qinghai & 8.65 & 1.82 & 0.48 & Yunnan & 6.78 & 10.74 & 0.63 \\
\hline Jilin & 7.72 & 14.7 & 0.52 & Hunan & 4.2 & 6.37 & 0.66 \\
\hline Neimenggu & 14.16 & 26.86 & 0.52 & Jiangxi & 6.73 & 9.64 & 0.69 \\
\hline Shanxi & 4.63 & 8.06 & 0.57 & Hainan & 5.87 & 8.24 & 0.71 \\
\hline Shaanxi & 5.22 & 8.97 & 0.58 & Anhui & 8.73 & 11.74 & 0.74 \\
\hline Sichuan & 6.82 & 11.84 & 0.58 & Guangxi & 8.49 & 11.47 & 0.74 \\
\hline Shandong & 4.45 & 7.53 & 0.59 & Guizhou & 3.83 & 5.09 & 0.75 \\
\hline Liaoning & 5.44 & 9.24 & 0.59 & Fujian & 7.8 & 9.37 & 0.83 \\
\hline
\end{tabular}

of pro-poor tourism villages. We superimposed the spatial distribution map of pro-poor tourism villages with altitude map of China, and calculated the number of pro-poor tourism villages in stages with an altitude of $500 \mathrm{~m}$ as an interval unit (Figure 3). We found that, as the altitude increases, the number of pro-poor tourism villages decreases sharply. The number of pro-poor tourism villages with an altitude of less than $500 \mathrm{~m}$ is the largest, accounting for $41.1 \%$, the proportion of pro-poor tourism villages with an altitude of $500 \mathrm{~m}$ to $1000 \mathrm{~m}$ dropped to $21.1 \%$. According to comprehensive statistics, the number of pro-poor tourism villages with an altitude of less than $1000 \mathrm{~m}$ accounted for $62.2 \%$. The unique geographical environment can cause poverty in the village and can also profoundly affect the development of tourism poverty alleviation. The distribution of tourism poverty alleviation villages is closely related to the three-level ladder-like distribution of China's topography. The first step is higher than $4000 \mathrm{~m}$ above sea level, mainly on plateaus, and there are few tourist poverty alleviation villages. The altitude of the second step is between 1000 and $2000 \mathrm{~m}$, and the terrain has large undulations, which is not conducive to population settlement and the development of rural tourism. The third stage is dominated by plains and hills, with small undulations, superior agricultural production conditions, and good geographic location, which are conducive to the development of rural tourism. Therefore, the concentration of tourism poverty alleviation villages is high. It shows that topography is the environmental foundation of tourism poverty alleviation villages, and China's antipoverty spatial pattern is affected by topography and landforms.

4.2. Annual Rainfall. Pro-poor tourism villages have the characteristics of traditional agricultural settlements. Agricultural development is very dependent on water. Rainfall is an important indicator reflecting regional climate characteristics. Abundant rainfall is the basis of agricultural production, and a livable environment is also a prerequisite for the development of rural tourism. The annual rainfall gradually increases from northwest to southeast. The annual rainfall is classified according to the equidistant method of $100 \mathrm{~mm}$ and superimposed with the spatial distribution of pro-poor tourism villages. Then, we counted the number of pro-poor tourism villages at each stage (Figure 3 ) and found that, under different rainfall conditions, there are significant differences in the number of tourism poverty alleviation villages. Figure 3 shows that, with the increase of rainfall, the number of pro-poor tourism villages presents an " $\mathrm{M}$ " distribution. When the rainfall is between $800 \mathrm{~mm}$ and $900 \mathrm{~mm}$, the number of tourist poverty alleviation villages is the largest, accounting for $13.7 \%$. When the annual rainfall is between $600 \mathrm{~mm}$ and $1000 \mathrm{~mm}$, the number of pro-poor tourism villages accounts for about 50\%. Except for extremely dry and humid areas, the number of poverty alleviation villages under different rainfall conditions accounted for more than 1\%. Rainfall over $800 \mathrm{~mm}$ is a humid area, and the number of tourism poverty alleviation villages reaches a peak around $800 \mathrm{~mm}$. It can be seen that the spatial distribution of tourism poverty alleviation villages is affected by rainfall.

4.3. Tourism Resource. Tourism resources are not only the prerequisite and foundation for the development of tourism but also the most basic factor that constitutes tourism activities [36]. Regions with rich tourism resources can lay a good foundation of resources and tourists for the construction of pro-poor tourism villages and the development of rural leisure tourism. There are abundant tourism resources in China, with various types of tourism resources such as natural landscape, history and culture, leisure, and entertainment. Tourism resources are mostly represented by scenic spots of different levels in China [30]. As of the end of 2018, there are 11,924 A-level scenic spots in China, and the high A-level scenic spots $(4 \mathrm{~A}, 5 \mathrm{~A})$ usually have complete infrastructure conditions and have formed a good brand effect, which can have a strong radiation effect on surrounding rural tourism [37]. Therefore, take the high A-level scenic spots $(4 \mathrm{~A}, 5 \mathrm{~A})$ as the center of the circle and use $10 \mathrm{~km}, 20 \mathrm{~km}, 30 \mathrm{~km}, 40 \mathrm{~km}$, and $50 \mathrm{~km}$ as the buffer radius to establish a buffer zone (Figure 4(a)).The measurement shows that pro-poor tourism villages in a $10 \mathrm{~km}$ buffer zone account for $13.6 \%$, in a $20 \mathrm{~km}$ buffer zone account for $36.6 \%$, in a $30 \mathrm{~km}$ buffer zone account for $56.9 \%$, in a $40 \mathrm{~km}$ buffer zone account for $71.5 \%$, and in a $50 \mathrm{~km}$ buffer zone account 


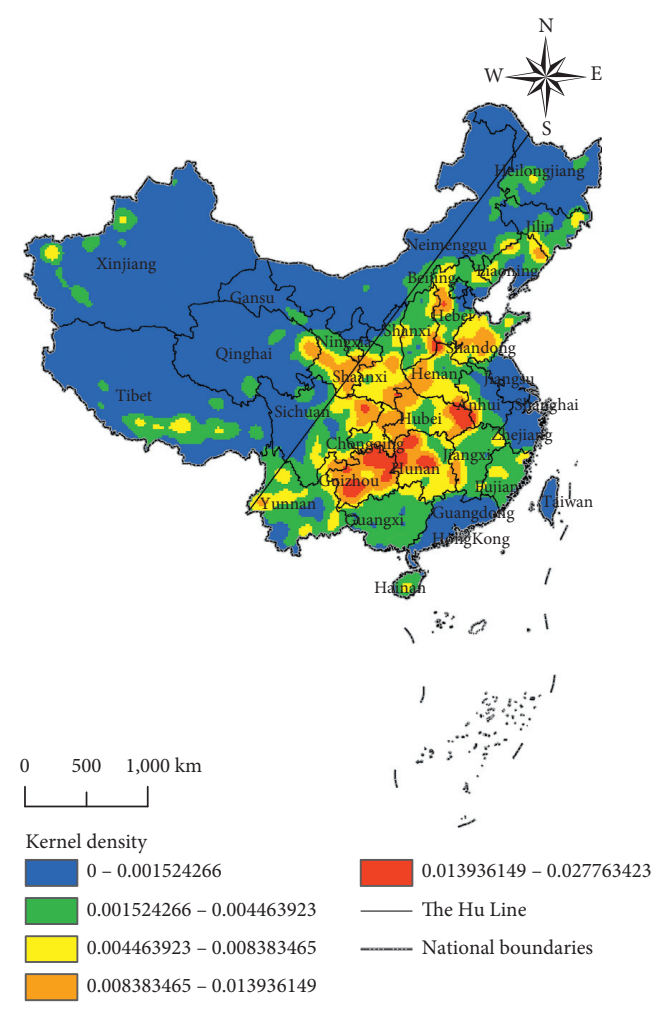

(a)

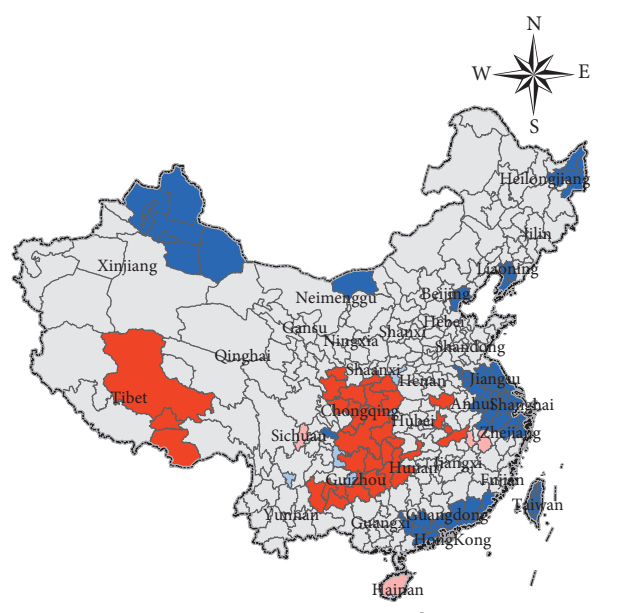

$\because 0.1$
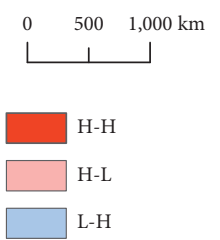

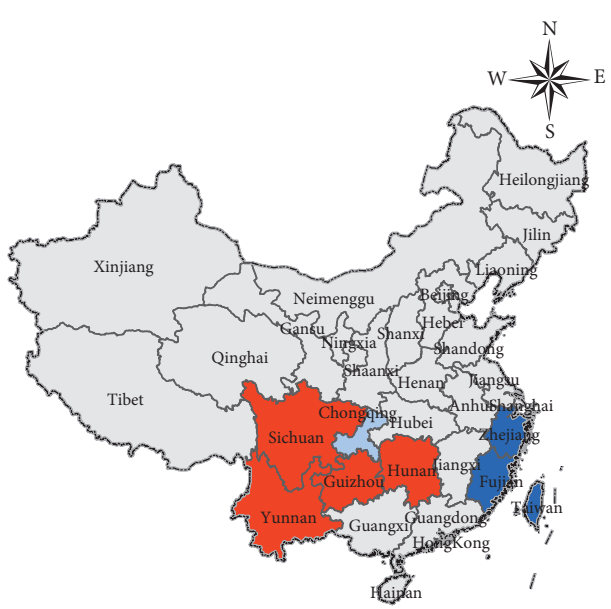

$\because 0.1$
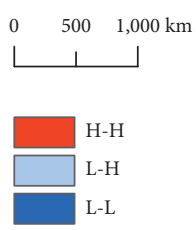

L-L

(b)

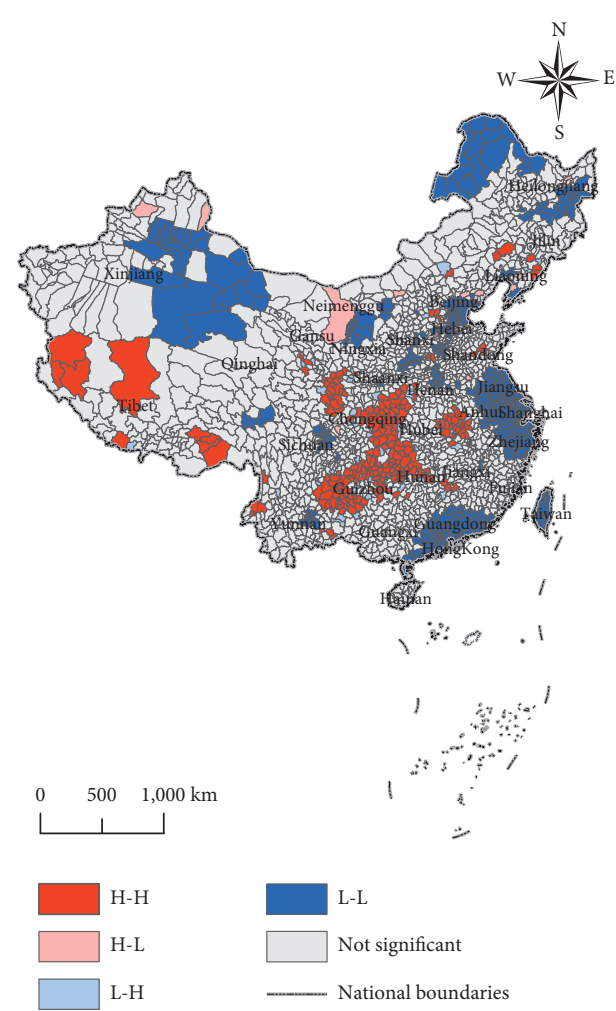

(d)

FIgURE 2: The spatial distribution characteristics map of pro-poor tourism villages in China.

for $80.8 \%$. With the increase of the buffer radius, the number of pro-poor tourism villages increases, and the pro-poor tourism villages are mainly concentrated in the buffer zone with a radius of $50 \mathrm{~km}$. This shows that the spatial distribution of pro-poor tourism villages is affected by the endowment of tourism resources. 
TABLE 2: Moran index of pro-poor tourism villages.

\begin{tabular}{lcccrr}
\hline Scale & Moran's I & E(I) & Sd & Z & \multicolumn{1}{c}{ P } \\
\hline Province & 0.319 & -0.0303 & 0.0804 & 4.3602 & 0.0009 \\
City & 0.438 & -0.0026 & 0.0268 & 16.4144 & 0.0001 \\
County & 0.398 & -0.0004 & 0.0112 & 35.5811 & 0.0001 \\
\hline
\end{tabular}

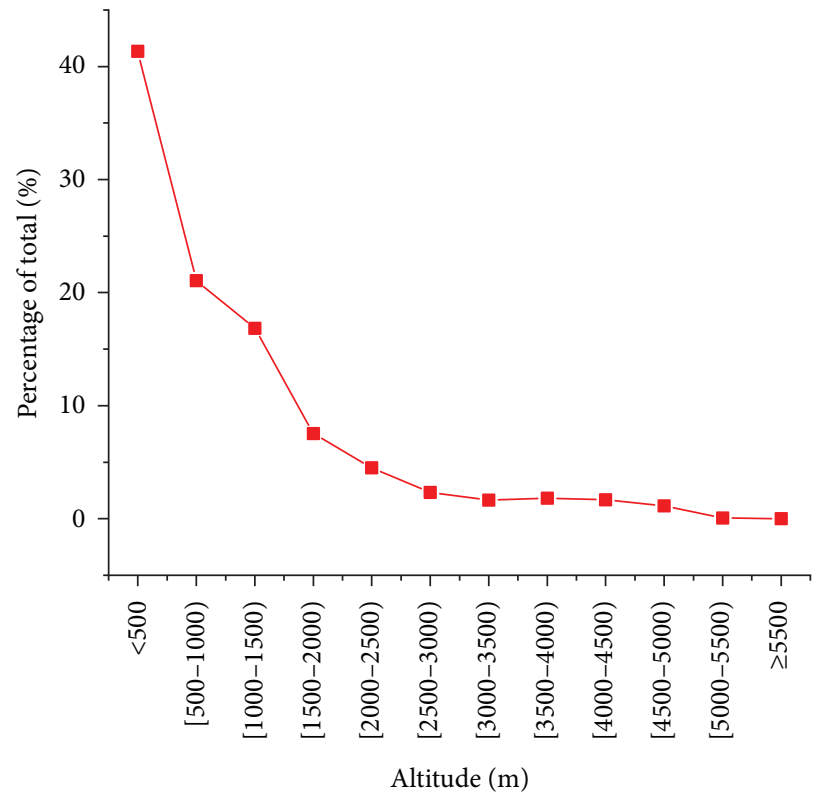

(a)

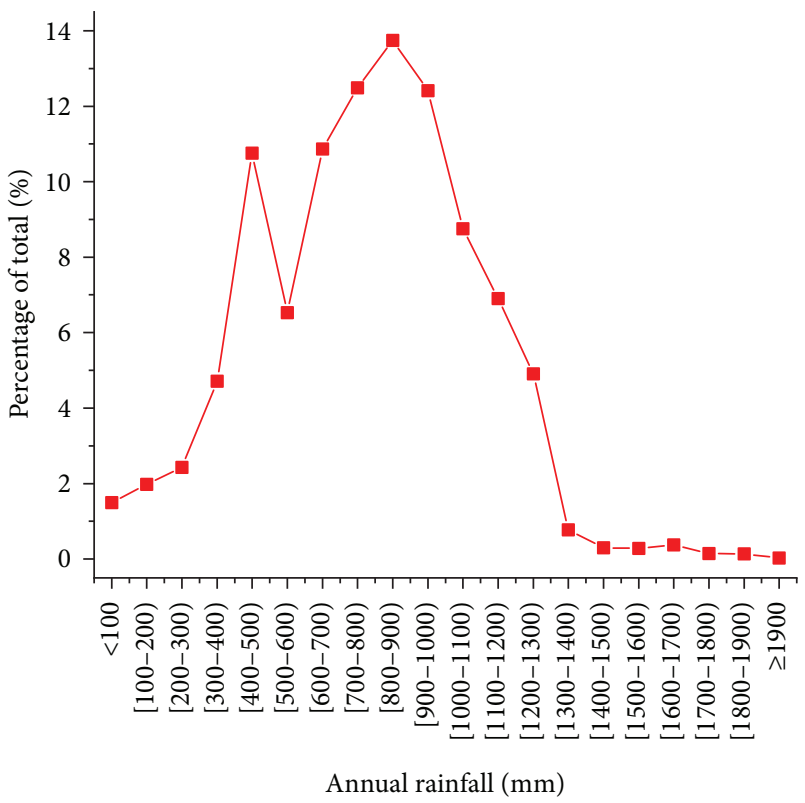

(b)

FIGURE 3: The influence of altitude and annual rainfall on the spatial distribution of tourism poverty alleviation villages.

4.4. Location and Traffic. The economic and cultural driving force of the eastern coastal areas is very strong, so the propoor tourism villages are sparsely distributed and the eastern coastal areas are L-L agglomeration areas. Due to geographical location conditions and natural environment restrictions, the economic radiation function of southwest China is relatively weak, so the pro-poor tourism villages are relatively distributed concentrated. The difference in economic development is an internal factor that affects the spatial distribution of pro-poor tourism villages.

Roads are a product of human activity and they not only bring economic prosperity but also have an important influence on the distribution of settlements along the route [38]. Pro-poor tourism villages mainly rely on tourism resources to develop rural leisure tourism, and their main source markets are concentrated in nearby markets, especially relying on land transportation. Therefore, a buffer zone was established for major road such as national highways and superimposed with the spatial distribution of pro-poor tourism villages (Figure 4(b)). With reference to the standard that tourists have a strong sense of experience, take $15 \mathrm{~km}$ and $40 \mathrm{~km}$ as the buffer radius, respectively, with the ride and self-driving of tourists to the main road within $1 \mathrm{~h}$ [30]. It is estimated that the pro-poor tourism villages in the buffer zone with a buffer radius of $15 \mathrm{~km}$ account for $39.2 \%$ and the pro-poor tourism villages in the buffer zone with a buffer radius of $40 \mathrm{~km}$ account for $72.6 \%$. It shows that most of the pro-poor tourism villages are located closer to the main roads and have good accessibility, indicating that traffic is one of the factors affecting the spatial distribution of pro-poor tourism villages. In areas far away from main roads, although there may be attractive original natural scenery and environment, it is difficult to develop tourism because of poor traffic accessibility, so there are fewer propoor tourism villages. To consolidate the results of poverty alleviation and accelerate the development of rural leisure tourism, pro-poor tourism villages must further break the traffic restrictions and increase their accessibility.

4.5. Policy Guidance. Pro-poor tourism is greatly affected by policies in China. Liu et al. [39] proved that the Tibet aid policy is conducive to the development of Tibet's tourism [40]. According to the spirit of the "China Rural Poverty Alleviation and Development Program (2011-2020)" promulgated in 2011 [41], 11 contiguous destitute areas including Liupan Mountain, Qinba Mountain, and Wuling Mountain have been divided in China. Besides, there are three prefectures that have clearly implemented special policy support in Tibet, Xinjiang, and other province. Therefore, there are a total of 14 contiguous destitute areas as the main battlefield for poverty alleviation (The Central People's Government of the People's Republic of China, 2011).We visualized the 14 contiguous destitute areas in 


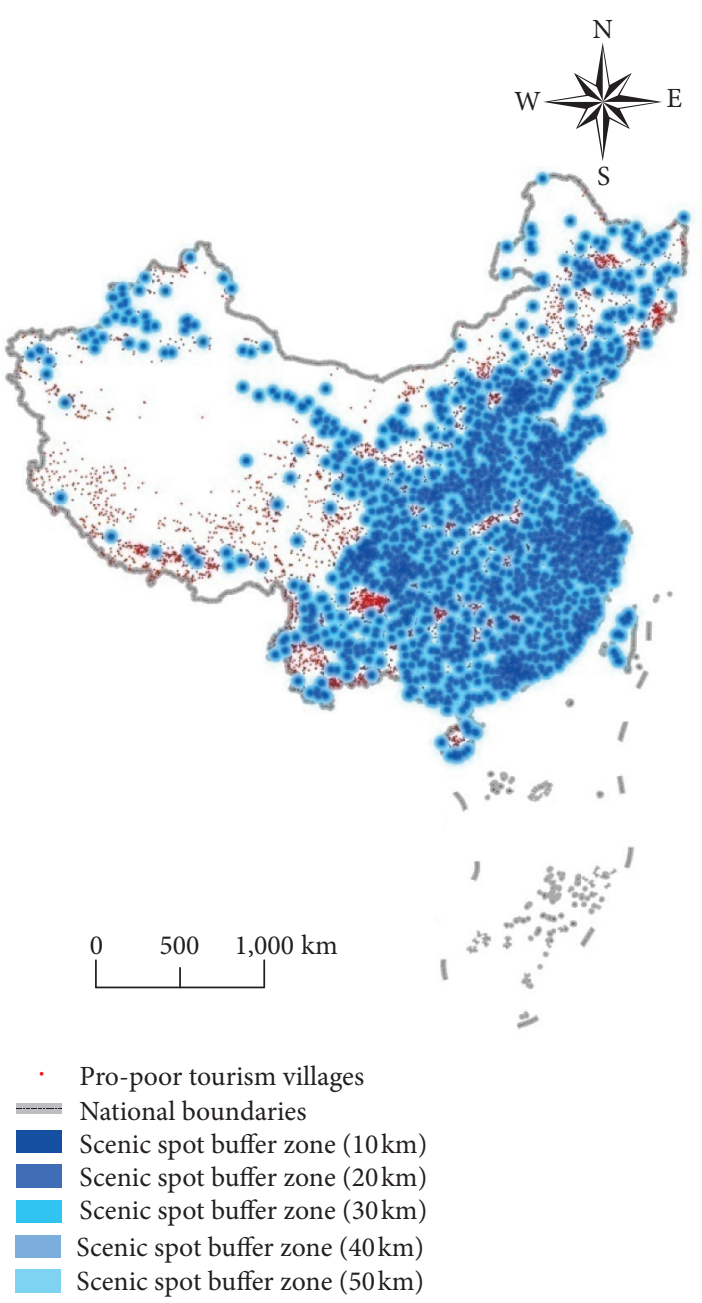

(a)

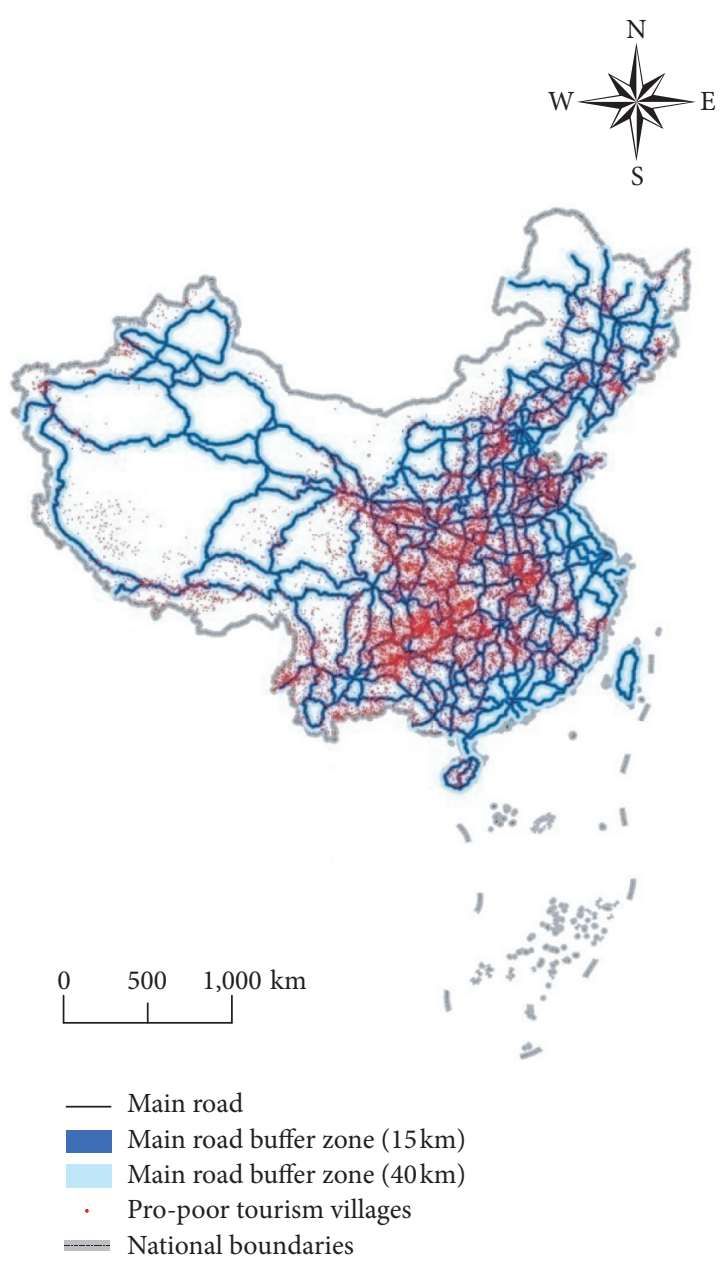

(b)

FIGURE 4: Coupling diagram of high A-level scenic spots buffer zone, main road buffer zone, and pro-poor tourism villages.

TABLE 3: The distribution of pro-poor tourism villages in contiguous destitute areas.

\begin{tabular}{|c|c|c|c|}
\hline Contiguous destitute areas & $\begin{array}{l}\text { Proportion } \\
\quad(\%)\end{array}$ & Contiguous destitute areas & $\begin{array}{l}\text { Proportion } \\
(\%)\end{array}$ \\
\hline Qinba Mountains & 9.49 & $\begin{array}{c}\text { Mountainous area on the western border of } \\
\text { Yunnan }\end{array}$ & 3.62 \\
\hline Wuling Mountain & 9.30 & Tibetan areas in four provinces & 3.43 \\
\hline $\begin{array}{l}\text { Yunnan, Guangxi, and Guizhou Rocky Desertification } \\
\text { Area }\end{array}$ & 6.87 & Yanshan-Taihang Mountains & 2.99 \\
\hline Liupanshan District & 4.86 & Luoxiao Mountain & 1.85 \\
\hline Tibet area & 4.79 & Three prefectures in southern Xinjiang & 1.28 \\
\hline Wumeng Mountains & 4.35 & $\begin{array}{c}\text { Mountain area in the southern foot of } \\
\text { Daxinganling }\end{array}$ & 1.00 \\
\hline Dabie Mountains & 3.65 & Luliang Mountain & 0.88 \\
\hline Total & 58.37 & - & - \\
\hline
\end{tabular}

ArcGIS 10.3 and performed overlay analysis on the spatial distribution of pro-poor tourism villages. We calculated the proportion of pro-poor tourism villages in each contiguous destitute area (Table 3 ). In general, the pro-poor tourism villages in 14 contiguous destitute areas accounted for
$58.37 \%$. It can be seen that there is a strong coupling between the concentrated areas of pro-poor tourism villages and the contiguous destitute areas.

From the perspective of each contiguous destitute area, the number of pro-poor tourist villages in the Qinba and 
Wuling Mountains is the largest, which is consistent with the results of local spatial autocorrelation. The economic development level of these contiguous destitute areas is relatively backward, but the tourism resources are rich. Because the local government's pro-poor tourism work started earlier, there are a large number of pro-poor tourism villages. Economically developed cities such as Beijing, Shanghai, Tianjin, and Jiangsu have strong economic radiation capabilities, so there are no pro-poor tourism villages, and the absence of pro-poor tourism villages in economically developed areas further reflects the country's obvious policy orientation in the layout. While taking into account the actual situation of the region, the underdeveloped regions are also taken into consideration, aiming to give full play to the leverage of tourism in poverty alleviation and truly achieve precise poverty alleviation [30].

\section{Conclusion and Policy Recommendations}

5.1. Conclusion. This paper combines mathematical statistical analysis and spatial statistical analysis methods to study the spatial distribution characteristics and influencing factors of pro-poor tourism villages and draws the following conclusions:

(1) The pro-poor tourism villages are widely distributed and partially concentrated; they present an uneven agglomeration pattern, and the degree of agglomeration varies greatly among provinces; the spatial distribution density is roughly bounded by the Heihe-Tengchong line, and the number of pro-poor tourism villages gradually increases from the northwest to the southeast inland, presenting a "core" distribution pattern. The southeast side of the $\mathrm{Hu}$ Line gathers most of China's GDP and population, but there are many tourist poverty alleviation villages, which is contrary to the traditional theory that economic growth can eliminate poverty. On the one hand, there may be a large economic gap between urban and rural areas in the southeast. On the other hand, there may be more tourism resources available for development in the southeast.

(2) The distribution of pro-poor tourism villages has $\mathrm{H}-\mathrm{H}$ and L-L spatial agglomeration characteristics, positive spatial correlation is dominant, and the degree of spatial agglomeration is the least obvious at the provincial scale. In areas where pro-poor tourism villages are sparsely distributed, the smaller the scale, the more scattered the spatial distribution. The distribution of $\mathrm{H}-\mathrm{H}$ and L-L agglomeration areas overlaps in different scales. The southwest region is a hotspot for the distribution of tourism poverty alleviation villages. On the one hand, it shows that this area is suitable for the development of rural tourism; on the other hand, it also shows that the population in this area is more likely to be poor again, and more attention should be paid in the future.

(3) The influencing factors of the spatial distribution of pro-poor tourism villages are complex and comprehensive. The topography, annual rainfall, and tourism resources in the natural environment are the environmental foundations for the formation of pro-poor tourism villages. The location transportation and policy orientation in social and economic factors are of great significance to the development of pro-poor tourism villages. It shows that the distribution of tourism poverty alleviation villages has little to do with the overall local economic development, and the livable environment of the countryside is very important. In the future, in the process of developing rural tourism and consolidating the results of poverty alleviation, more attention should be paid to creating a comfortable and livable environment.

5.2. Policy Recommendations. The spatial distribution of pro-poor tourism villages can be regarded as a problem of regional poverty alleviation and the development of rural tourism. Now, the poverty alleviation work has entered a sprint stage in China, accelerating the development of rural leisure tourism and realizing the integration of agriculture and tourism have become the key to consolidating the results of poverty alleviation and achieving comprehensive poverty alleviation. We put forward the following suggestions for the future development of pro-poor tourism villages based on the above research results:

(1) Pro-poor tourism villages have $\mathrm{H}-\mathrm{H}$ agglomeration areas, and the local centralized distribution pattern is conducive to breaking the problems of fragmented rural tourism layout and single content and is conducive to exploring the new rural tourism agglomeration development model of the "pointline-surface" trinity. In this way, a linear economy of "food, housing, travel, shopping, and entertainment" will be formed, and an interconnected rural tourism area will be created.

(2) The natural geographical environment is the environmental foundation of the pro-poor tourism villages. Most of the pro-poor tourism villages are located in the plains and low hilly areas with low altitude and abundant rainfall. The agriculture in these areas is developed, and it is possible to rationally design a series of projects integrating agriculture and tourism, such as "forestry+ amusement," "breeding + pasture life experience," and "fishery + fishing experience," on the basis of respecting the agricultural industry, so as to create rural agricultural tourism and leisure destination. In addition, the scattered pro-poor tourism villages in areas with higher altitudes and less rainfall develop tourism which is often costly. The government can consider "relocation" to solve the problem of population poverty, not to carry out large-scale renovations, to preserve the original environment, and to attract tourists with the spirit of adventure to carry out extreme outdoor sports. 
(3) The abundant tourism resources in China have laid the foundation for the development of rural leisure tourism in pro-poor tourism villages, and most of the pro-poor tourism villages are distributed around tourism resources. The "National Eco-tourism Development Plan (2016-2025)" pointed out that, by 2025, China will become the leading eco-tourism country. Therefore, in the future, pro-poor tourism villages should pay more attention to the protective development of original ecological natural resources, rationally excavate representative regional cultural symbols, develop characteristic tourism products, and gradually promote the development of rural eco-tourism.

(4) The influencing factors of the distribution of pro-poor tourism villages indicate that they have a strong dependence on land transportation. Therefore, the transportation facilities of pro-poor tourism villages must be further improved. Transportation facilities include not only external transportation but also internal roads, parking lots, service stations, and characteristic rural trails of the pro-poor tourism villages. Transportation facilities are related to the accessibility of rural tourist attractions and the number of tourists attracted.

(5) The above research shows that the spatial distribution of pro-poor tourism villages has a strong policy orientation. In the process of social and economic development, policies can take into account poor areas and adjust the gap in economic development between regions. Moreover, the multifunctionality of rural tourism determines the richness of its specific projects, and policies are needed to provide guarantees for them. In the future, it is necessary to further refine the relevant policies related to rural tourism resource management property rights transactions, rural tourism financing, rural tourism land, and rural tourism benefit distribution, so as to build a policy network system to ensure the further release of rural tourism benefits, such as agricultural benefits, poverty alleviation, and environmental protection [42].

\section{Data Availability}

The data used in this study are available from the corresponding author upon request (E-mail:zhfthero45@ cqut.edu.cn).

\section{Conflicts of Interest}

The authors declare no conflicts of interest.

\section{Authors' Contributions}

The study was designed by Q. Y. (YangQing); the data from professional websites were retrieved by Y. A. (YouzhiAn),
C. S. (ChangchenSun), and Y. Z. (ZhangYue); Q. Y. wrote the manuscript; F. Z. (Fengtai Zhang) provided important ideas and suggestions.

\section{Acknowledgments}

This research was funded by the Project of National Key Research and Development Program of China in the 13th Five-year Plan Period (Grant no. 2016YFC0502606), Science and Technology Research Program of Chongqing Municipal Education Commission (Grant no. KJQN201901129), Humanities and Social Sciences Research Program of Chongqing Municipal Education Commission (Grant no. 19SKGH132), Chongqing Social Science Planning Project (2019YBGL075), and Scientific Research Foundation of Chongqing University of Technology.

\section{References}

[1] R. Scheyvens, "Exploring the tourism-poverty nexus," Current Issues in Tourism, vol. 10, no. 2-3, pp. 231-254, 2007.

[2] Q. Wan and Q. X. Fan, "A review of researches on poverty alleviation by tourism at home and abroad," Rural Economy and Science-Technology, vol. 30, no. 23, pp. 122-126, 2019.

[3] H. Y. Wu, "Research on the deelopment model and spatial distribution pattern of rural tourism in Chongqing based on accurate poverty alleviation," Chinese Journal of Agricultural Resources and Regional Planning, vol. 40, no. 10, pp. 244-249, 2019.

[4] D. Schilcher, "Growth versus equity: the continuum of pro-poor tourism and neoliberal governance," Current Issues in Tourism, vol. 10, no. 2-3, pp. 166-193, 2007.

[5] H. Q. Li, L. C. Hou, S. W. Yang et al., "Progress in research on poverty alleviation by tourism abroad," Human Geography, vol. 30, no. 1, pp. 26-32, 2015.

[6] G. Man and E. Jones, "Community-based tourismenterprises development in Kenya: an exploration oftheir potential as avenues of poverty reduction," Journal of Sustainable Tourism, vol. 15, no. 6, pp. 628-644, 2007.

[7] M. Medina, R. Diego, and P. Gutierrez, "The impacts of tourism on poverty alleviation: anintegrated research framework," Journal of Sustainable Tourism, vol. 24, no. 2, pp. 270-298, 2016.

[8] J. Bowden, "Pro-poor tourism and the Chinese experience," Asia Pacific Journal of Tourism Research, vol. 10, no. 4, pp. 379-398, 2005.

[9] B. Zeng and C. Ryan, "Assisting the poor in China through tourism development: a review of research," Tourism Management, vol. 33, no. 2, pp. 239-248, 2012.

[10] M. Mowforth, E. Cater, and G. Lowman, "Ecotourism: a sustainable option?" The Geographical Journal, vol. 162, no. 1, pp. 102-104, 1996.

[11] R. Lorca, M. Carmen, J. A. C. Casas et al., "Tourism and poverty alleviation: an empirical analysisusing panel data on Peru's departments," International Journal of Tourism Research, vol. 19, no. 16, pp. 746-756, 2017.

[12] W. Zhao and J. R. B. Ritchie, "Tourism and poverty alleviation: an integrative research framework," Current Issues in Tourism, vol. 10, no. 2-3, pp. 119-143, 2007.

[13] J. Macbeth, C. Warren, and S. Chok, “Tourism asa tool for poverty alleviation: a critical analysis of pro-poor tourism and implications for sustainability," Current Issues in Tourism, vol. 10, no. 2-3, pp. 144-165, 2007. 
[14] H. Job and F. Paesler, "Links between nature-based tourism, protected areas, poverty alleviation and crises-The example of Wasini Island (Kenya)," Journal of Outdoor Recreation and Tourism, vol. 1-2, no. 3, pp. 18-28, 2013.

[15] W. Rid, I. O. Ezeuduji, and U. Pröbstl-Haider, "Segmentation by motivation for rural tourism activities in the Gambia," Tourism Management, vol. 40, no. 2, pp. 102-116, 2014.

[16] R. Scheyvens and M. Russell, "Tourism and poverty alleviation in Fiji: comparing the impacts of small- and large-scale tourism enterprises," Journal of Sustainable Tourism, vol. 20, no. 3, pp. 417-436, 2012.

[17] R. B. Powell, T. F. Green, P. J. Holladay et al., "Examining community resilience to assist in sustainable tourism development planning in dong van karst plateau geopark, vietnam," Tourism Planning \& Development, vol. 15, no. 4, pp. 436-457, 2018.

[18] J. Briedenhann and E. Wickens, “Tourism routes as a tool for the economic development of rural areas-vibrant hope or impossible dream?" Tourism Management, vol. 25, no. 1, pp. 71-79, 2004.

[19] R. Scheyvens, "Backpacker tourism and third world development," Annals of Tourism Research, vol. 29, no. 1, pp. 144-164, 2002.

[20] K. Kennedy and D. A. Dornan, "An overview: tourism nongovernmental organizations and poverty reduction in developing countries," Asia Pacific Journal of Tourism Research, vol. 14, no. 2, pp. 183-200, 2009.

[21] R. Scheyvens and M. Russell, "Tourism, land tenure and poverty alleviation in Fiji," Tourism Geographies, vol. 14, no. 1, pp. 1-25, 2012.

[22] E. E. Ezebilo, L. Mattsson, and C. A. Afolami, "Economic value of ecotourism to local communities inthe Nigerian rainforest zone," Journal of Sustainable Development, vol. 3, no. 1, pp. 51-60, 2010.

[23] G. T. Phi, M. Whitford, and S. Reid, "What's in theblack box? Evaluating antipoverty tourism interventions utilizing theory of change," Current Issues in Tourism, vol. 21, no. 17, pp. 1930-1945, 2018.

[24] W. Anderson, "Cultural tourism and poverty alleviation in rural Kilimanjaro, Tanzania," Journal of Tourism and Cultural Change, vol. 13, no. 3, pp. 208-224, 2015.

[25] C. M. Rogerson, "The challenges of developing adventure tourism in South Africa," Africa Insight, vol. 37, no. 2, pp. 228-244, 2007.

[26] E. Steinicke and M. Neuburger, "The impact of community-based afro-alpine tourism on regional development," Mountain Research and Development, vol. 32, no. 4, pp. 420-430, 2012.

[27] M. J. Zapata, C. M. Hall, P. Lindo, and M. Vanderschaeghe, "Can community-based tourism contribute to development and poverty alleviation? lessons from Nicaragua," Current Issues in Tourism, vol. 14, no. 8, pp. 725-749, 2011.

[28] Q. Qin, Z. L. Hu, A. L. Liu, Y. Huang, and F. Zhang, Identification and evolution of the noncoordination coupling relationship between tourism poverty alleviation and ecological environments in poor mountainous areas," Discrete Dynamics in Nature and Society, vol. 2020, Article ID 5094863, , 2020.

[29] V. D. Truong, "Pro-poor tourism: looking backward as we move forward," Tourism Planning \& Development, vol. 11, no. 2, pp. 228-242, 2014.

[30] L. Zhu, J. Hu, X. T. Xu et al., "Spatial distribution pattern and causes of poverty alleviation by tourism in China," China Population, Resources and Environment, vol. 26, no. 11, pp. 130-138, 2016.
[31] Q. Wu, X. G. Li, and M. Zhang, "Study on spatial pattern and affecting factors of agriculture tourism destination in Hubei Province," Areal Research and Development, vol. 36, no. 1, pp. 158-163, 2017.

[32] Z. Xie and J. Yan, "Kernel density estimation of traffic accidents in a network space," Computers, Environment and Urban Systems, vol. 32, no. 5, pp. 396-406, 2008.

[33] O. Berke, "Exploratory disease mapping: Kriging the spatial risk function from regional count data," International Journal of Health Geography, vol. 3, no. 1, p. 18, 2004.

[34] B. W. Silverman, Density Estimation for Statistics and Data Analysis, Chapman and Hall, New York, NY, USA, 1986.

[35] W. R. Tobler, "A computer movie simulating urban growth in the detroit region," Economic Geography, vol. 46, no. Supp 1, pp. 234-240, 1970.

[36] Q. Wu, "Spatial pattern and influencing factors of pro-poor tourism areas in Guangdong Province," Research on Development, vol. 35, no. 4, pp. 116-121, 2019.

[37] T. Wang and P. F. Tai, "Spatial differentiation and its influencing factors of national rural tourism destination in Shandong Province," Economic Geography, vol. 36, no. 1I, pp. 161-168, 2016.

[38] N. Li and S. Jiang, "Study on spatial pattern of rural settlements in wuling mountainous area based on GIS," Wireless Personal Communications, vol. 102, no. 4, pp. 2745-2757, 2018.

[39] S. Liu, X. Xie, X. F. Zhang, C. Zhou, and Y. Cai, “Coordinated development between assistance to Tibet and Tourism development: spatial patterns and influencing factors," Discrete Dynamics in Nature and Society, vol. 2020, 2020.

[40] The State Council Leading Group Office of Poverty Alleviation and Development, "Jinping Xi: Speech at the Forum on Decisive Battle against Poverty," 2020, http://www.cpad.gov. cn/art/2020/3/6/art_3141_114201.html.

[41] The Central People's Government of the People's Republic of China, "China's rural poverty alleviation and development program (2011-2020)," 2011, http://www.gov.cn/gongbao/ content/2011/content_2020905.htm.

[42] J. Ma and B. Y. Shu, "30 years of rural tourism in China: policy orientation, reflection and optimization," Modern Economic Research, vol. 27, no. 4, pp. 116-122, 2020. 